\title{
Propolis: anti-Staphylococaus aureus activity and synergism with antimicrobial drugs
}

\section{Ary Fernandes Júnior ${ }^{+}$, Elaine Cristina Balestrin, Joyce Elaine Cristina Betoni, Ricardo de O liveira O rsi, Maria de Lourdes Ribeiro de Souza da Cunha, Augusto Cezar Montelli}

\author{
Departamento de Microbiologia e Imunologia, Instituto de Biociências, Universidade Estadual Paulista Julio de Mesquita Filho, \\ Unesp, 18618-000 Botucatu, SP, Brasil
}

Propolis is a natural resinous substance collected by bees from tree exudates and secretions. Its antimicrobial activity has been investigated and inhibitory action on Staphylococcus aureus growth was evaluated. The in vitro synergism between ethanolic extract of propolis (EEP) and antimicrobial drugs by two susceptibility tests (Kirby and Bauer and E-Test) on $25 \mathrm{~S}$. aureus strains was evaluated. Petri dishes with sub-inhibitory concentrations of EEP were incubated with 13 drugs using Kirby and Bauer method and synergism between EEP and five drugs [choramphenicol (CLO), gentamicin (GEN), netilmicin (NET), tetracycline (TET), and vancomycin (VAN)] was observed. Nine drugs were assayed by the E-test method and five of them exhibited a synergism [CLO, GEN, NET, TET, and clindamycin (CLI)]. The results demonstrated the synergism between EEP and antimicrobial drugs, especially those agents that interfere on bacterial protein synthesis.

Key words: propolis - Staphylococcus aureus - Kirby and Bauer method - E-test method - antimicrobial drugs

Propolis is a complex resinous material produced by honeybees from plant exudates, beeswax, and bee secretions (Kusumoto et al. 2001) and is responsible for safety of honeycombs, especially against microorganisms (Bosio et al. 2000). The chemical composition of Apis mellifera propolis and its wide spectrum of biological activities (hepatoprotective, antitumour, antioxidative, antimicrobial, and antiinflammatory properties) have attracted the attention of researchers (Banskota et al. 2001). It is composed of $50 \%$ resin and vegetable balsam, 30\% wax, $10 \%$ essential and aromatic oils, 5\% pollen, and 5\% several substances, including organic debris, but this composition varies according to the vegetal source (Burdock 1998). The mechanism of antimicrobial activity of propolis is complex and could be attributed to the synergistic activity between phenolic and other compounds (Krol et al. 1993) mainly to the flavonoids pinocembrin, galangin, and pinobanksin (Castaldo \& Capasso 2002). A stronger activity was observed on gram-positive bacteria growth (Burdock 1998). The antimicrobial activity was observed on Staphylococcus aureus (Krol et al. 1993, Fernandes Júnior et al. 1995, 1997, 2001, 2003, Sforcin et al. 2000); Streptococcus pyogenes (Bosio et al. 2000); gram-positive and gram-negative bacteria species and Candida (Drago et al. 2000, Sforcin et al. 2000, Stepanovic et al. 2003); Streptococcus mutans (Koo et al. 2002); anaerobic bacteria of human oral cavity (Santos et al. 2002); Salmonella (Orsi et al. 2005), and on miscellaneous microorganisms including Mycobacterium (Banskota et al. 2001). Antibacterial activity of propolis on $S$. aureus growth was higher when

Financial support: Fapesp

${ }^{+}$Corresponding author. Email : ary@ibb.unesp.br

Received 7 April 2005

Accepted 20 July 2005 ethanolic extracts were prepared with 60 to $80 \%$ ethanol solutions (Fernandes Júnior et al. 2003). In vitro synergism between propolis and antimicrobial drugs has been investigated (Kedzia \& Holderna 1986, Detoma \& Ozino 1991, Krol et al. 1993, Scheller et al. 1999, Stepanovic et al. 2003) and preparations of propolis with antibiotics and antifungals are of potential medical interest (Stepanovic et al. 2003).

Antimicrobial susceptibility methods used in clinical laboratories are based on the principle of diffusion, known as the Kirby and Bauer test (disk diffusion) and E- test (strip diffusion). The E-test method is based on a combination of concepts of both dilution and diffusion tests. The drugs are impregnated in a strip an antimicrobial density gradient is established in an agar plate and minimal inhibitory concentration (MIC) in $\mathrm{mg} / \mathrm{ml}$ are evaluated (Mahon \& Manuselis 1995). The aim of the present work was to investigate in vitro synergism between propolis ethanolic extract (EEP) and anti-S. aureus drugs performed by Kirby and Bauer and E-test methods.

\section{MATERIALS AND METHODS}

Ethanolic extract of propolis (EEP) - A crude sample of Apis mellifera propolis was collected from apiary in Botucatu School of Veterinary Medicine and Animal Husbandry, Unesp, São Paulo State University, Brazil. EEP was obtained diluting $25 \mathrm{~g}$ crude propolis in $100 \mathrm{ml}$ of $70 \%$ ethanol, and extracted at room temperature. After three days the extract was filtered (Whatman paper) and kept at refrigerator temperature.

S. aureus strains - Sixty-one $S$. aureus strains were isolated from clinical specimens of newborns admitted to the Neonatal Unit of the University Teaching Hospital, Botucatu, state of São Paulo, Brazil. Strains were isolated in Sheep's blood agar and after identification (Koneman et al. 1997) were stored in brain heart infusion (BHI) plus agar. 
Minimal inhibitory concentration (MIC) of propolis - Concentration (MIC) of EEP was determined for $61 S$. aureus strains by diluting the extract in Mueller-Hinton Agar (MHA) media (\% volume/volume), as recommended (NCCLS 2002). Petri plates containing concentrations of EEP varying from 0.2 to $13 \% \mathrm{v} / \mathrm{v}$, control plates without EEP and $70 \%$ ethanol control were inoculated with $S$. aureus strains $\left(10^{5} \mathrm{CFU}\right)$ using a Steers replicator, and incubated at $37^{\circ} \mathrm{C} / 24 \mathrm{~h}$. The concentration, that inhibited visible growth of each strain (MIC), was recorded and the MIC $90 \%$ was calculated.

Synergism assays between EEP and other antimicrobial drugs - In vitro synergism assays were carried out after evaluating the EEP MIC. One-fourth of MIC 90\% was considered as sub-inhibitory concentration of EEP in the synergism assays (Mahon \& Manuselis 1995). Synergism assays were carried out on $25 \mathrm{~S}$. aureus strains, including one ATCC 13565 , according two diffusion methods (Kirby and Bauer and E-test) on Mueller-Hinton agar (MHA). Thirteen drugs were evaluated by disk diffusion method: penicillin $10 \mathrm{UI}$ (PEN), oxacillin $1 \mathrm{mg}$ (OXA), vancomycin $30 \mathrm{mg}$ (VAN), ampicillin $10 \mathrm{mg}$ (AMP), cephalothin $30 \mathrm{mg}$ (CFL), cefoxitin $30 \mathrm{mg}$ (CFO), choramphenicol $30 \mathrm{mg}$ (CLO), gentamicin $10 \mathrm{mg}$ (GEN), netilmicin $30 \mathrm{mg}$ (NET), tetracycline $30 \mathrm{mg}$ (TET), erythromycin $15 \mathrm{mg}$ (ERI), cotrymoxazol $25 \mathrm{mg}$ (SUT), and ofloxacin $5 \mathrm{mg}$ (OFX). Two antibiogram sets in duplicate were performed for each $S$. aureus strains in control plates with plain MHA and in plates containing MHA plus one-fourth of MIC $90 \%$ of EEP. On Kirby and Bauer method (NCCLS 2002), diameters (millimeter) of inhibitory zones were recorded after incubation at $37^{\circ} \mathrm{C} / 18 \mathrm{~h}$. In addition to OXA, VAN, CFL, CLO, GEN, NET, and TET, evaluated by disk diffusion, two other drugs, clindamycin (CLI) and rifampicin (RIF) were also evaluated by the E-test method. The antibacterial activity $(\mu \mathrm{g} / \mathrm{ml})$ was recorded by observing the elliptical inhibitory areas for each strip (Mahon \& Manuselis 1995) after incubation at $37^{\circ} \mathrm{C} / 18 \mathrm{~h}$.

Statistical analysis - Results from synergism assays were submitted to the Mann-Whitney non-parametric test comparing the values $(\mathrm{mm})$ of the inhibitory zone in the disk diffusion method and the values of the MIC $(\mu \mathrm{g} / \mathrm{m})$ from the E-test method (Minitab Statistical Software version 13.32). Results were considered significant when $\mathrm{p}<0.05$.

\section{RESULTS AND DISCUSSION}

MIC 90\% of EEP and 70\% ethanol control are shown in Figure. The EEP showed a MIC $90 \%$ of $0.4 \% \mathrm{v} / \mathrm{v}$ and the $70 \%$ ethanol control was higher than $13 \% \mathrm{v} / \mathrm{v}$. These values were similar to those reported by Fernandes Júnior et al. (1995, 1997, 2001) and Sforcin et al. (2000). The antibacterial activity of EEP when compared to $70 \%$ ethanol control shows that substance combinations were responsible for the action of propolis and not the ethanol in the EEP. Although the properties of propolis have been the subject of several investigations, it is difficult to compare the results of different studies, due to the different compositions and/or different methods used for the evaluation of propolis antibacterial activities.

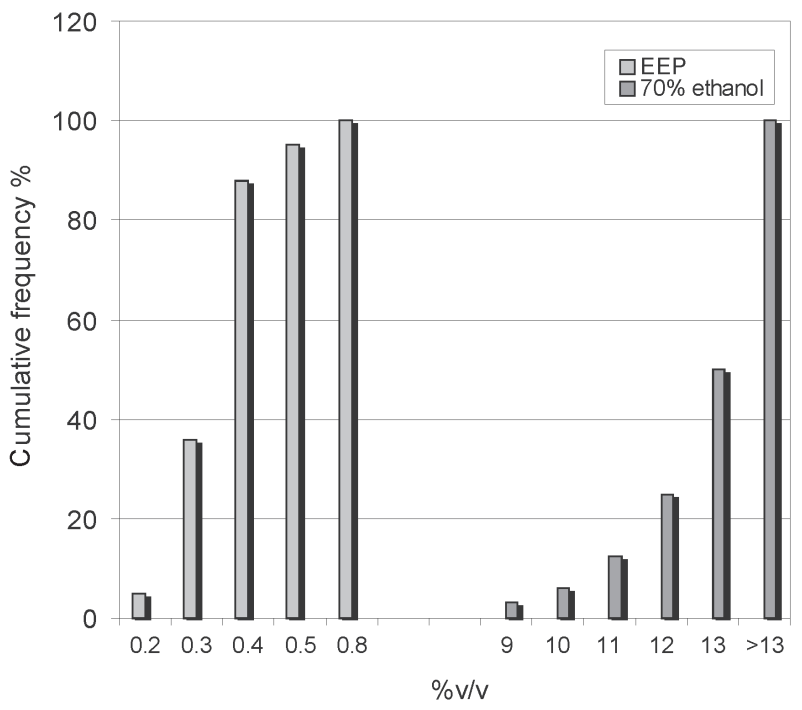

Cumulative frequency of inhibition of Staphylococcus aureus growth by ethanolic extract of propolis and 70\% ethanol control (EEP MIC $90 \%=0.40 \% \mathrm{v} / \mathrm{v}$ and $70 \%$ ethanol control MIC $90 \%>13 \% \mathrm{v} / \mathrm{v})$.

The results of in vitro synergism from the Kirby and Bauer and E-test method are presented in Tables I and II, respectively. Kirby and Bauer and E-test methods revealed synergism between EEP with five drugs (CLO, GEN, NET, TET, VAN, and CLO, GEN, NET, TET, CLI respectively). The synergism with drugs that inhibit protein synthesis (CLO, GEN, NET, TET, CLI) and absence of antagonism between the EEP and all drugs tested are important observations of present study and, to the best of our knowledge is being shown by E-test method for the first time. These results were identical for Kirby and Bauer and Etest methods and, although the E-test method shows MIC $(\mu \mathrm{g} / \mathrm{ml})$ values for each drug, the disk diffusion method could be employed in studies with similar objectives because it is more economic. Results similar to ours were reported previously by disk diffusion method (Kedzia \& Holderna 1986, Detoma \& Ozino 1991, Krol et al. 1993, Scheller et al. 1999, Stepanovic et al. 2003).

Some mechanisms of the activity of propolis on bacterial growth have been reported: (1) inhibition of cell division; (2) bacterial cytoplasm, cell membranes, and cell walls collapse; (3) bacteriolysis; and (4) protein synthesis inhibition (Takaisi-Kikuni \& Schilcher 1994). Galagin and caffeic acid from EEP are enzymatic inhibition agents in bacteria (Havsteen 1983, Ikeno et al. 1991, Koo et al. 2002). The RNA-polymerase inhibition by propolis compounds was verified (Takaisi-Kikuni \& Schilcher 1994) and can explain partially the synergism of EEP with drugs that act by inhibiting protein synthesis observed here. However, we consider these as preliminary results and the establishment of the molecular basis of synergistic effect between EEP and drugs with action is on bacteria protein synthesis is necessary.

Thus, the results presented in the present report were encouraging although clinical controlled studies are needed to define the real efficacy. These studies could 
TABLE I

Inhibitory effect of antimicrobial agents on 25 Staphylococcus aureus isolates during exposure to ethanolic extract of propolis (EEP), evaluated by Kirby and Bauer method

\begin{tabular}{lccr}
\hline & \multicolumn{2}{c}{ Zone diameter in mm: median (range) } & \multicolumn{1}{c}{$\mathrm{p}^{a}$} \\
\cline { 2 - 3 } Antimicrobial agent & MHA without EEP & MHA with EEP & 0.031 \\
Chloramphenicol & $27.5(10-31)$ & $29.0(10-35)$ & 0.007 \\
Gentamicin & $24.0(0-28)$ & $26.0(0-31)$ & 0.001 \\
Netilmicin & $26.0(13-30)$ & $29.5(17-36)$ & 0.005 \\
Tetracycline & $24.0(8-27)$ & $27.5(9-35)$ & 0.017 \\
Vancomycin & $20.5(19-23)$ & $22.0(19-24)$ & 0.088 \\
Cotrimoxazol & $32.0(0-35)$ & $33.0(0-39)$ & 0.397 \\
Ofloxacin & $28.5(10-33)$ & $29.0(9-32)$ & 0.441 \\
Cephalothin & $34.5(8-44)$ & $37.0(9-43)$ & 0.392 \\
Ampicillin & $22.0(9-45)$ & $25.0(10-45)$ & 0.382 \\
Penicillin & $23.0(9-48)$ & $25.5(9-48)$ & 0.210 \\
Cefoxitin & $29.0(0-33)$ & $30.5(0-33)$ & 0.350 \\
Erythromycin & $23.5(0-27)$ & $24.5(0-34)$ & 0.447 \\
Oxacillin & $26.5(0-30)$ & $26.0(0-30)$ & \\
\hline
\end{tabular}

MHA: Mueller Hinton Agar; $a$ : significant difference when $\mathrm{p}$ values $<0.05$

TABLE II

Inhibitory effect of antimicrobial agents on 25 Staphylococcus aureus isolates during exposure to ethanolic extract of propolis (EEP), evaluated by minimal inhibitory concentration (MIC) determination

\begin{tabular}{lccr}
\hline & \multicolumn{2}{c}{ MIC $^{a} \mu \mathrm{g} / \mathrm{ml}$ : median (range) } & \multicolumn{1}{c}{$\mathrm{p}^{b}$} \\
\cline { 2 - 3 } Antimicrobial agent & MHA without EEP & MHA with EEP & 0.023 \\
Chloramphenicol & $3.0(2-192)$ & $2.0(1-96)$ & $<0.001$ \\
Gentamicin & $0.75(0.023-256)$ & $0.19(0.047-256)$ & $<0.001$ \\
Netilmicin & $0.75(0.5-24)$ & $0.25(0.047-12)$ & $<0.001$ \\
Tetracycline & $1.5(0.75-64)$ & $0.38(0.094-32)$ & $<0.001$ \\
Clindamycin & $0.094(0.064-256)$ & $0.047(0.023-256)$ & 0.312 \\
Vancomycin & $1.5(1-2)$ & $1.5(0.75-2)$ & 0.684 \\
Oxacillin & $0.25(0.094-256)$ & $0.19(0.125-256)$ & 0.676 \\
Cephalothin & $0.19(0.094-256)$ & $0.19(0.094-64)$ & 0.984 \\
Rifampicin & $0.016(0.016-20)$ & $0.016(0.016-10)$ & \\
\hline
\end{tabular}

MHA: Mueller Hinton Agar; $a$ : E-test method; $b$ : significant difference when p values $<0.05$

determine the potential medical use of propolis in combination with certain antimicrobial drugs on staphylococci diseases. Since bacteria may be resistant to several antimicrobial drugs, the synergism reported here is of relevance and propolis may constitute an alternative for treating these pathogens.

\section{ACKNOWLEDGMENTS}

To Luciano Barbosa (Departamento de Matemática e Bioestatística/ IBB/UNESP/Botucatu) for statistical analysis.

\section{REFERENCES}

Banskota AH, Tezuka Y, Kadota S 2001. Recent progress in pharmacological research of propolis. Phytother Res 15: 561-571.

Bosio K, Avanzini C, D'avolio A, Ozimo O, Savoia D 2000. In vitro activity of propolis against Streptococcus pyogenes. Lett Appl Microbiol 31: 174-177.

Burdock GA 1998. Review of the biological properties and toxicity of bee propolis (Propolis). Food Chem Toxicol 36: 347-363.
Castaldo S, Capasso F 2002. Propolis, an old remedy used in modern medicine. Fitoterapia 73 (Suppl. 1): S1-S6.

Detoma P, Ozino OL 1991. Azione della propoli su microrganismi dell'ambiente ospedalino. Ann Microbiol Enzimol 41: 231-236.

Drago 1, Mombelli B, De Vecchi E, Fassina MC, Tocalli L, Gismondo MR 2002. In vitro antimicrobial activity of propolis dry extract. J Chemotherapy 12: 390-395.

Fernandes Júnior A, Balestrin ECC, Cunha MLRS 2003. AntiStaphylococcus aureus activity of bee propolis extracts prepared with different ethanol concentrations. Rev Ciênc Farm 24: 147-152.

Fernandes Júnior A, Leomil L, Fernandes AAH, Sforcin JM 2001. The antibacterial activity of propolis produced by Apis mellifera L. and Brazilian stingless bees. J Venom Anim Toxins 7: 173-182.

Fernandes Júnior A, Lopes CAM, Sforcin JM, Funari SRC 1997. Population analysis of susceptibility to propolis in reference strains of Staphylococcus aureus and Escherichia coli. J Venom Anim Toxins 3: 287-294. 
Fernandes Júnior A, Sugizaki MF, Fogo ML, Funari SRC, Lopes CAM 1995. In vitro activity of propolis against bacterial and yeast pathogens isolated from human infections. $J$ Venom Anim Toxins 1: 63-69.

Havsteem B 1983. Flavonoids, a class of natural products of high pharmacology potency. Biochem Pharmacol 32: 11411148.

Ikeno K, Ikeno T, Miyazawa C 1991. Effects of propolis on dental caries in rats. Caries Res 25: 347-351.

Kedzia B, Holderna E 1986. Investigations upon the combined action of antibiotics and propolis on Staphylococcus aureus. Herba Polonica 32: 187-195.

Koneman EW, Allen SD, Janda NM, Sshrechkenberger PC, Winn JR 1997. Color Atlas and Textbook of Diagnostic Microbiology, 5th ed., JB Lippincott, Philadelphia, 1395 pp.

Koo H, Rosalen PL, Cury JA, Park YK, Bowen WH 2002. Effects of compounds found in propolis on Streptococcus mutans growth and on glucosiltransferase activity. Antimicrob Agents Chemother 46: 1302-1309.

Krol W, Scheller S, Shani J, Pietsz G, Czuba Z 1993. Synergistic effect of ethanolic extract of propolis and antibiotics on the growth of Staphylococcus aureus. Arzneimittel-forsch 43: 607-609.

Kusumoto T, Miyamoto RH, Doi S, Hiroyuki S, Yamada H 2001. Isolation and structures of two new compounds from the essential of Brazilian propolis. Chem Pharm Bull 49: 1207-1209.

Mahon CR, Manuselis JR G 1995. Textbook of Diagnostic Mi- crobiology, WB Saunders, Philadelphia, 1134 pp.

NCCLS-National Committee for Clinical Laboratory Standards 2002. Performance standards for antimicrobial disk susceptibility tests, document M100-S12, Pennsylvania.

Orsi RO, Sforcin JM, Rall VLM, Funari SRC, Barbosa L, Fernandes Júnior A 2005. Susceptibility profile of Salmonella against the antibacterial activity of propolis produced in two regions of Brazil. J Venom Anim Toxins incl Tropl Dis 11: 109-116.

Santos FA, Bastos EMA, Uzeda B, Carvalho MAR, Farias ESA, Braga FC 2002. Antibacterial activity of Brazilian propolis and fractions against oral anaerobic bacteria. $J$ Ethnopharmacol 80: 1-7.

Scheller S, Dworniczak S, Waldemar KK, Rajca M, Tomczik A, Shani J 1999. Synergism between ethanolic extract of propolis (EEP) and anti-tuberculosis drugs on growth of mycobacteria. Z Naturforsch C 54: 549-553.

Sforcin JM, Fernandes Júnior A, Lopes CAM, Bankova V, Funari SRC 2000. Seasonal effect on Brazilian propolis antibacterial activity. J Ethnopharmacol 73: 243-249.

Stepanovic S, Antic N, Dakic I, Svabic-Vlahovic M 2003. In vitro antimicrobial activity of propolis and synergism between propolis and antimicrobial drugs. Microbiol Res 158: 353-357.

Takaisi-Kikuni NB, Schilcher H 1994. Electron microscopy and microcalorimetric investigations of the possible mechanism of the antibacterial action of a defined propolis provenance. Planta Medica 60: 222-227. 